\title{
Analysis of Lymphatic Filariasis Case Distribution for Preparing Environmental Based Elimination Strategy in Brebes Regency, Indonesia
}

\author{
Arum Siwiendrayanti ${ }^{1}$, Eram Tunggul Pawenang ${ }^{2}$, Yuni Wijayanti ${ }^{3}$, Widya Hary Cahyati ${ }^{4}$ \\ \{a_shiwi@mail.unnes.ac.id ${ }^{1}$, eramtepe@mail.unnes.ac.id ${ }^{2}$, yuniwija@mail.unnes.ac.id ${ }^{3}$ \} \\ Universitas Negeri Semarang, Semarang, Indonesia ${ }^{1,2,3,4}$
}

\begin{abstract}
Brebes Regency is a new endemic area for lymphatic filariasis in Central Java Province, Indonesia, which has farming area and coastal area. This study aimed to analyze the lymphatic filariasis cases distribution in Brebes Regency for preparing environmental strategy of elimination. This was a descriptive study with spatial and documentary approach. The scope of location covered all subdistricts. The lymphatic filariasis case distribution was analyzed spatially. The analysis of zero case subdistricts vulnerability and environmental control preparation were composed based on previous studies and secondary data. The result showed that most cases were located on farming area. The zero case subdistricts were vulnerable. Three concepts of environmental control approaches were composed. It was concluded that elimination program in Brebes Regency should prior the farming areas. It was a unique finding that the previous studies told the contrary that coastal areas were more vulnerable for lymphatic filariasis.
\end{abstract}

Keywords: lymphatic filariasis, case distribution, filariasis endemic area, coastal area, farming area.

\section{Introduction}

Lymphatic filariasis or elephantiasis is caused by parasitic infections classified as nematodes from the Filariodidea family. There are three types of filaria worms namely Wuchereria bancrofti, Brugia malayi, and Brugia timori. Lymphatic filariasis is spread by various mosquitoes like Culex, Aedes, Anopheles, Armigeres, and Mansonia.[1,2] World Health Organization (WHO) had launched the elimination of lymphatic filariasis program which was targeted to achieve it in 2020. But especially in Central Java Province, Indonesia, in the last two years the number of regencies / cities that have endemic filariasis had increased from 2 to 9 . The strategy from WHO in eliminating lymphatic filariasis were by mass drug administration, environmental control, and management of clinical cases of lymphatic filariasis. Lymphatic filariasis elimination strategies from WHO faced different challenges in each country that applies them. Considering local conditions is needed in 
implementing the elimination strategies, especially in environmental control aspect where conditions can be very different in each region.[1]

Lymphatic filariasis endemic area is an area which has more than $1 \%$ percentage of microfilaria positive blood sample. Central Java Province, Indonesia, before 2017 only had 2 endemic areas, namely Pekalongan Regency and Pekalongan City. After 2017, Central Java Province had 9 regencies/cities as lymphatic filariasis endemic areas, namely Pekalongan City, Pekalongan Regency, Brebes Regency, Wonosobo Regency, Semarang Regency, Grobogan Regency, Blora Regency, Pati Regency and Demak Regency. The highest number of new case findings in Central Java occurred in Brebes Regency. The number of lymphatic filariasis case in Brebes Regency had increased from year to year. Lymphatic filariasis cases in 2016 in Brebes Regency numbered 25, increased to 54 in 2017, and increased to 65 in 2018.

Brebes Regency has unique condition in space. It has combination between farming area and coastal area. Brebes Regency is famous because of its red onion commodity which dominate its farming areas. Besides red onion, Brebes Regency also has rice, corn, potato, and various fruits commodities. Brebes Regency is also known as salted eggs producer. Therefore, duck farming is also often found there. The other livestock in Brebes Regency are cow, buffalo, goats, and sheep. Brebes has several subdistricts bordering the seashore which are famous with its mangrove tourism track. Those all have potency to be mosquito breeding places. Slum farming areas and puddles can be mosquito breeding and resting places in farming areas.[3-7] Likewise, slum coastal settlements and tidal flood can be mosquito breeding and resting places in coastal areas. [8-14] This study aimed to analyze the distribution of lymphatic filariasis cases in Brebes Regency for preparing suitable environmental based strategy for lymphatic filariasis elimination.

\section{Methods}

This was a descriptive study with spatial and documentary approach. The scope of location covered all subdistricts in Brebes Regency. Lymphatic filariasis case data were collected from Health Office of Brebes Regency. The data were confirmed to each Public Health Center (Puskesmas) in Brebes Regency. The lymphatic filariasis case was analyzed spatially to determine its distribution in farming area and coastal area. The number of lymphatic filariasis case was written down on each subdistrict on the Brebes Regency map taken from id.wp-Wic2020 (Lisensi Bebas GNU, Version 1.2). The data for analyzing the vulnerability of zero case subdistricts were collected from Statistic Central Bureau of Brebes Regency, Central Java Environment Agency, and Agricultural Office of Brebes Regency with documentary approach. The environmental based elimination strategy preparation was composed based on previous studies and secondary data from Statistic Central Bureau of Brebes Regency, Central Java Environment Agency, and Agricultural Office of Brebes Regency. 


\section{$3 \quad$ Results and Discussions}

\subsection{Spatially Distribution of Lymphatic Filariasis Case in Brebes Regency}

The most cases of lymphatic filariasis were located on Ketanggungan Subdistrict. It is a farming area or non-coastal area. Ketanggungan Subdistrict is one of the red onion farming centers in Brebes Regency.[15] Red onion farming area is wetland farm or agricultural land with pooled water. This pooled water of red onion farmland had the potential to become a breeding place for mosquitoes.[16] Ketanggungan Subdistrict also had the second highest of cow livestock population. Several studies proofed the correlation between the presence of cattle pens and lymphatic filariasis case. $[10,16,17]$ The subdistrict with second highest number of lymphatic filariasis cases is Paguyangan Subdistrict which is also an agricultural or non-coastal area. Agricultural commodities from Paguyangan Subdistrict are rice, cassava, corn, and sweet potatoes. Rice field area is wetland farm or agricultural land with pooled water. It could be a breeding place for mosquitoes.[16] The cassava, corn, and sweet potato farming areas were dry land farms or plantation lands without pooled water. Plantation land with a lot of plants and shrubs could also be a resting place for mosquitoes. $[3,10]$ Paguyangan Subdistrict had the highest position in poultry eggs and cow milk. It was closely related to raising cattle and poultry. Duck farming needed pooled water scape which could be breeding place for mosquitoes. Cattle pen could be resting place for mosquitoes and previously proofed related to lymphatic filariasis case by several studies.[10,16,17]

Subdistrict with the highest number of lymphatic filariasis cases in Brebes Regency was not in the coastal area. It was a different finding from some previous studies. Previous studies had found that lymphatic filariasis cases were more prevalent in coastal areas. Slums and tidal flood were strongly suspected of being mosquito breeding and resting places. The limited socioeconomic capacity of coastal settlers also made it more difficult for improving environmental conditions in coastal areas.[8-10] Several studies had corelated mangrove ecosystem condition with mosquito density. Those studies explained that undisturbed mangrove ecosystem would become a habitat for mosquitoes so that mosquitoes did not fly towards settlement areas. This was indicated by the higher mosquito density in the mangrove area and the lower mosquito density in the settlement area. The condition of mangrove ecosystem that were disturbed due to human activities caused mosquitoes to lose their habitat so that they fly towards the settlement area. This resulted in a higher density of mosquitoes in the settlement. [11,14,18,19] Several other studies linking the condition of mangrove ecosystems with the spread of mosquito-borne diseases. When the mangrove ecosystem was disturbed, mosquitoes flied towards the settlement. The higher density of mosquitoes in settlements increased the risk of transmitting mosquitoborne diseases. De Souza's et al. (2012) research showed that mosquitoes around disturbed mangrove areas were the type of mosquito that spreads disease. [20-23] Data from the Central Java Environment Agency showed that Brebes Regency had good mangrove quality and quantity in space. It could keep mosquito population in the mangrove area and not fly to the settlement. However, further research is needed to confirm this. 


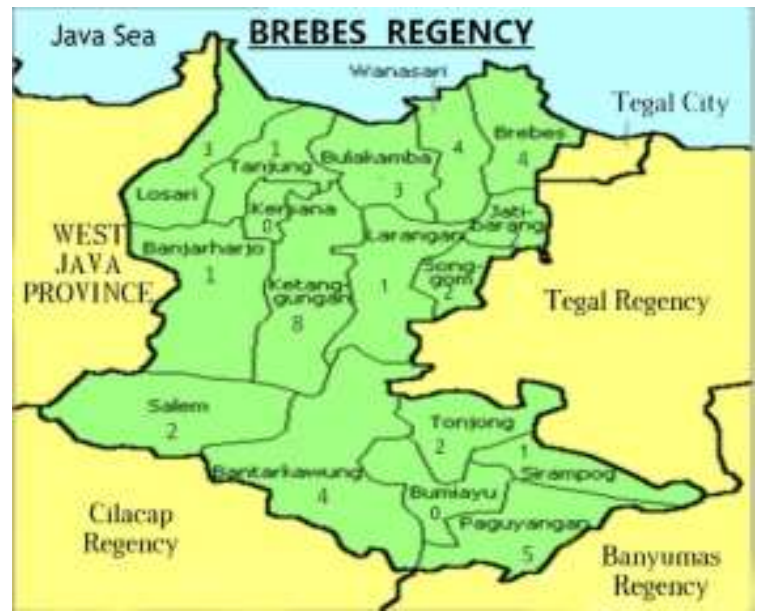

Fig. 1. Distribution of lymphatic filariasis case number in Brebes Regency. [Modified from id.wp-Wic2020 (Lisensi Bebas GNU, Version 1.2)]

\subsection{The Vulnerability of the Zero Case Subdistricts in Brebes Regency}

There were 2 subdistricts which did not have lymphatic filariasis cases, namely Kersana Subdistrict and Bumiayu Subdistrict. Both of them should be prevented from lymphatic filariasis transmission. Table 1 detailed aspects that illustrate the vulnerability of the two subdistricts to transmission of filariasis.

Kersana Subdistrict was bordered with Ketanggungan Subdistrict which had the highest number of lymphatic filariasis case and also bordered with other subdistricts which had lymphatic filariasis cases. It would increase the risk of lymphatic filariasis transmission because mosquitoes could fly to the nearest area. This concern was reinforced by the existence of environmental conditions that support mosquito breeding and resting. Kersana Subdistrict had $45.5 \mathrm{Ha}$ dry land farm and also 175 cows and buffaloes. Dry land farm with a lot of plants and shrubs could also be a resting place for mosquitoes. $[3,10]$ Presence of cattle pens would increase the risk of lymphatic filariasis because the cattle would attract the mosquito and the cattle pens were suitable for mosquito resting place.[10,16,17] Kersana Subdistrict also had 3,020 Ha wetland farm consisted of paddy field and red onion farm. The pooled water on wetland farm was suitable for mosquitoes breeding place.[16]

Bumiayu Subdistrict was bordered with Paguyangan Subdistrict which had the second highest number of lymphatic filariasis case and also bordered with other subdistricts which had lymphatic filariasis cases. It would increase the risk of lymphatic filariasis transmission because mosquitoes could fly to the nearest area. This concern was reinforced by the existence of environmental conditions that support mosquito breeding and resting. Bumiayu Subdistrict had 4,163 Ha dry land farm and also 1,411 cows and buffaloes. Dry land farm with a lot of plants and shrubs could also be a resting place for mosquitoes. $[3,10]$ Presence of cattle pens would increase the risk of lymphatic filariasis because the cattle would attract the mosquito and the cattle pens were suitable for mosquito resting place.[10,16,17] Bumiayu Subdistrict also had 12,076 Ha wetland farm consisted of paddy 
field and red onion farm. The pooled water on wetland farm was suitable for mosquitoes breeding place.[16]

Table 1. The vulnerability of the zero lymphatic filariasis case subdistricts in Brebes Regency.

\begin{tabular}{|c|c|c|}
\hline Subdistrict & Risk factors & Protective factors \\
\hline Kersana & $\begin{array}{l}\text { Bordered with the highest cases subdistrict (Ketanggungan). } \\
\text { Surrounded by other districts that had cases. } \\
\text { Has } 2,154 \text { Ha paddy field area. } \\
\text { Has } 866 \text { Ha red onion farm. } \\
\text { Has } 175 \text { cows and buffaloes. } \\
\text { Has } 45.5 \text { Ha dry land farm. }\end{array}$ & $\begin{array}{l}\text { The highest usage } \\
\text { of pesticides. }\end{array}$ \\
\hline Bumiayu & $\begin{array}{l}\text { Bordered with the second highest cases subdistrict (Pa- } \\
\text { guyangan). } \\
\text { Surrounded by other districts that had cases. } \\
\text { Has } 7,913 \text { Ha paddy field area. } \\
\text { Has } 1,411 \text { cows and buffaloes. } \\
\text { Has 4,163 Ha dry land farm. }\end{array}$ & $\begin{array}{l}\text { Has no red onion } \\
\text { farm. }\end{array}$ \\
\hline
\end{tabular}

Both Kersana Subdistrict and Bumiayu Subdistrict had many risk factors of lymphatic filariasis transmission. They were surrounded by the other subdistricts which had lymphatic filariasis cases and had potential environment conditions which were suitable for mosquito breeding and resting. Bumiayu Subdistrict has a protection factor in the form of the absence of shallot farmland where onion farmland is at risk of becoming a breeding place for mosquitoes because there is standing water. However, Bumiayu Subdistrict had a wider total of wetland and dryland farming areas than Kersana Subdistrict. The number of cattle in Bumiayu Subdistrict was also higher than Kersana Subdistrict. In addition, Kersana Subdistrict was recorded as the subdistrict with the highest level of pesticide use in Brebes Regency. Excessive use of pesticides could kill mosquito larvae and adult mosquitoes. This would reduce the risk of lymphatic filariasis transmission, even though the overuse of pesticide could endanger the environment and human health.[24-27] It could be stated that both Kersana Subdistrict and Bumiayu Subdistrict are vulnerable for lymphatic filariasis transmission, but Bumiayu Subdistrict is more vulnerable.

\subsection{The Concept of Environmental Based Elimination Strategy in Brebes Regency}

There were three concepts composed based on the risk and protective factors explained previously. They should be implemented in farming area, coastal area, and settlement which were detailed in Table 2. 
Table 2. The Concept of Environmental Based Elimination Strategy in Brebes Regency.

\begin{tabular}{ll}
\hline \multicolumn{1}{c}{ Area } & \multicolumn{1}{c}{ Environmental Prevention } \\
\hline Farming area & For wetland farming (paddy field and red onion farm): \\
& Implementing Minapadi System where fish are released into pooled \\
& water on agricultural wetlands. \\
& $\begin{array}{l}\text { For dry land farming (field of potato, corns, etc.): } \\
\text { Keeping the field tidy without herbages and shrubs and keeping } \\
\text { enough space between agricultural crops. }\end{array}$ \\
\hline Coastal area & Maintaining the sustainability of mangrove ecosystems. \\
\hline Settlement area & $\begin{array}{l}\text { Keeping cattle pens not connected directly with the dwelling house. } \\
\text { Installing mosquito wire net to house vents. }\end{array}$ \\
\hline
\end{tabular}

The application of the Minapadi system is expected to prevent mosquito breeding. Fish can eat mosquito larvae. The Minapadi system has long been known in Indonesia by placing fish in agricultural wetlands so that beside harvesting crops it can also harvest fish. However, there are some obstacles in the application of Minapadi system, including the phenomenon of fish theft from land and contamination of pesticides that will poison the fish. If this Minapadi is focused on controlling the transmission of lymphatic filariasis, it is better to choose larvivourous fish than production fish so that the fish is not stolen. Regarding the use of pesticides, it is recommended to use them in wisely and it would be better to implement organic farming system without pesticides. Organic farming without pesticides is safer for the environment and human health.[16,28-30] Shrubs and herbages could be resting places for mosquitoes. Keeping the dry land farm tidy and keeping enough space between agricultural crops would reduce its probability to be resting places for mosquitoes.[4,10,31]

The condition of mangrove ecosystem that were disturbed due to human activities caused mosquitoes to lose their habitat so that they fly towards the settlement area. This resulted in a higher density of mosquitoes in the settlement. Maintaining the sustainability of mangrove ecosystems would result in many benefits, not only preventing lymphatic filaria transmission but also protecting coastal area from abrasion and severe impact of disaster. $[11,14,18,19]$

The villagers used to place the cattle pens close to and even connected with their houses for reasons of avoiding cattle theft and also limited land. Whereas several studies had proven that close cattle pens to house will increase the risk of lymphatic filariasis transmission because livestock and their pens would attract mosquitoes. If it is not possible to move away the cattle pens from the house, efforts must be made to ensure that the cattle pens are not integrated with the house. Even if it is integrated with the house, it must be separated with a permanent wall without any hollows. Installing a mosquito wire net to house vents will prevent mosquitoes from entering the house. Filariasis is transmitted through mosquito bites. Preventing the entry of mosquitoes into the house will reduce the risk of transmission of filariasis. It should be implemented settlement areas both on farming and coastal areas.[3,16,17] 


\section{Conclusions}

Conclusion of this study was that the greatest number of lymphatic filariasis cases were spatially located on farming area subdistricts. It was a unique finding that the previous studies told the contrary that coastal areas were more vulnerable for lymphatic filariasis. Further studies are needed to explain both specific risk factor of lymphatic filariasis in Brebes Regency's farming area and protective factor of it in Brebes Regency's coastal areas. They were two zero case subdistricts in Brebes Regency which needed to be prevented from lymphatic filariasis transmission. Both of them were vulnerable for lymphatic filariasis transmission, but Bumiayu Subdistrict was more vulnerable. Three concepts of environmental control approaches were composed. These should be implemented in farming areas, coastal areas, and settlement areas both on farming and coastal areas.

\section{Acknowledgments}

We gratefully thank the Faculty of Sport Science of Universitas Negeri Semarang for funding this study through Flagship College Program (Penelitian Unggulan Perguruan Tinggi) 2020.

\section{References}

[1] World Health Organization. Global Programme to Eliminate Lymphatic Filariasis: Managing Morbidity and Preventing Disability. World Heal. Organ. Geneva-Switzerland: Department of Control of Neglected Tropical Diseases (NTD) World Health Organization; 2013.

[2] Eldridge BF, Edman JD, editors. Medical Entomology--A Textbook in Public Health and Veterinary Problems Caused by Arthropods. Revised Ed. Dordrecht: Springer Science+Business Media, B.V.; 2004.

[3] Siwiendrayanti A, Pawenang ET, Indarjo S. Spatial analysis and behavior evaluation to identify differentiating factors of filariasis endemic status. Adv Sci Lett. 2017;

[4] Khikmah N, Pawenang ET. Review of Environmental Aspects and Community Behavior in the Determination of Filariasis Risk Vulnerability Zone. Unnes J Public Heal. 2018;7:38-49.

[5] Okon OE, Iboh CI, Opara KN. Bancroftian filariasis among the Mbembe people of Cross River state, Nigeria. J Vector Borne Dis. 2010;47:91-6.

[6] Upadhyayula SM, Mutheneni SR, Kadiri MR, Kumaraswamy S, Nagalla B. A cohort study of lymphatic filariasis on socio economic conditions in Andhra Pradesh, India. PLoS One. 2012;7:1-8.

[7] Mutheneni SR, Upadhyayula SM, Kumaraswamy S, Kadiri MR, Nagalla B. Influence of socioeconomic aspects on lymphatic filariasis: A case-control study in andhra pradesh, India. J Vector Borne Dis. 2016;53:272-8.

[8] Nurjazuli, Santjaka A. Potential Sources of Transmission and Distribution of Lymphatic Filariasis in Semarang City, Central Java, Indonesia. Unnes J Public Heal. 2020;9:43-9.

[9] Nurjazuli N, Setiani O, Lubis R. Analysis of Lymphatic Filariasis Transmission Potential in Pekalongan City , Central Java , Indonesia. Asian J Epidemiol. 2018;11:20-5.

[10] Siwiendrayanti A, Pawenang ET, Indarjo S, Hikmah IH. Filariasis Vulnerability Zonation Based on Environmental and Behavioural Aspects in Pekalongan City , Indonesia Filariasis Vulnerability Zonation Based on Environmental and Behavioural Aspects in Pekalongan City , Indonesia. IOP Conf Ser Earth Environ Sci. IOP Publishing; 2020. p. 448012016. 
[11] Ismail TNST, Kassim NFA, Rahman AA, Yahya K, Webb CE. Day biting habits of mosquitoes associated with mangrove forests in Kedah, Malaysia. Trop Med Infect Dis. 2018;3:1-8.

[12] Siwiendrayanti A, Pawenang ET, Windraswara R, Wijayanti Y. Sequential Neighborhood Filariasis Transmission in Coastal Areas of Demak Regency, Indonesia. Adv Soc Sci Educ Humanit Res. Semarang: Atlantis Press; 2019. p. 241-5.

[13] Claflin SB, Webb CE. Surrounding land use significantly influences adult mosquito abundance and species richness in urban mangroves. Wetl Ecol Manag. 2017;25:331-44.

[14] de Souza AS, Couri MS, Florindo L. The Impact of Industrial Anthropization on Mosquito (Diptera, Culicidae) Communities in Mangrove Areas of Guanabara Bay (Rio de Janeiro, Brazil). Neotrop Entomol. 2012;41:68-73.

[15] BPS Statistics of Brebes Regency. Brebes Regency in Figures 2020. Brebes: BPS Statistics of Brebes Regency; 2020.

[16] Juwita F, Cahyati WH, Yuniastuti A. Risk Factors of Filariasis in Brebes Regency. Public Heal Perspect J. 2020;5:137-46.

[17] Syuhada Y, Nurjazuli, W NE. Study Of Environmental And Behavioral As Risk Factor Of Filariasis In District Of Buaran And Tirto Pekalo. Kesehat Lingkung Indones. 2012;11:95-101.

[18] Masela DF. Pengaruh Struktur dan Komposisi Mangrove bagi Kerapatan Nyamuk di Desa Kopi dan Desa Minanga Kecamatan Bintauna. Daniel F. Masela/ 080317009. COCOS. 2012;1:1-8.

[19] Kojongian G, Pijoh VD, Bernadus JBB. Survei Nyamuk Anopheles spp di Pesisir Selat Lembeh Kota Bitung. J Kedokt Klin. 2016;1:37-45.

[20] Putra AK, Bakri S, Kurniawan B. Peranan Ekosistem Hutan Mangrove pada Imunitas terhadap Malaria: Studi di Kecamatan Labuhan Maringgai Kabupaten Lampung Timur. J Sylva Lestari. 2015;3:67-78.

[21] Wigaty L, Bakri S, Santoso T, Wulan S. R. Wardani D. Pengaruh Perubahan Penggunaan Lahan Terhadap Angka Kesakitan Malaria: Studi Di Provinsi Lampung. J Sylva Lestari. 2016;4:1-10.

[22] Palaniyandi M, Anand P, Maniyosai R. Spatial cognition : a geospatial analysis of vector borne disease transmission and the environment, using remote sensing and GIS. Int J Mosq Res IJMR. 2014;1:39-54.

[23] Ramasamy R, Surendran SN. Global climate change and its potential impact on disease transmission by salinity-tolerant mosquito vectors in coastal zones. Front. Physiol. 2012.

[24] Kibuthu TW, Njenga SM, Mbugua AK, Muturi EJ. Agricultural chemicals: Life changer for mosquito vectors in agricultural landscapes? Parasites and Vectors. Parasites \& Vectors; 2016;9:1-9.

[25] Siwiendrayanti A, W NE. Hubungan Riwayat Pajanan Pestisida Dengan Kejadian Gangguan Fungsi Hati ( Studi pada Wanita Usia Subur di Kecamatan Kersana Kabupaten Brebes ) Association Between Pesticides Exposure and Liver Disfunction ( Study on women childbearing-age at Kecamatan Ker. J Kesehat Lingkung Indones. 2012;11:9-14.

[26] Emidi B, Kisinza WN, Mmbando BP, Malima R, Mosha FW. Effect of physicochemical parameters on Anopheles and Culex mosquito larvae abundance in different breeding sites in a rural setting of Muheza, Tanzania. Parasites and Vectors. Parasites \& Vectors; 2017;10:1-12.

[27] Gardner AM, Anderson TK, Hamer GL, Johnson DE, Varela KE, Walker ED, et al. Terrestrial vegetation and aquatic chemistry influence larval mosquito abundance in catch basins, Chicago, USA. Parasites and Vectors. 2013;6:1-11.

[28] Sinka ME, Bangs MJ, Manguin S, Chareonviriyaphap T, Patil AP, Temperley WH, et al. The dominant anopheles vectors of human malaria in the Asia-Pacific region: Occurrence data distribution maps and bionomic précis. Parasites and Vectors. 2011;4.

[29] El-Zeiny A, El-Hefni A, Sowilem M. Geospatial techniques for environmental modeling of mosquito breeding habitats at Suez Canal Zone, Egypt. Egypt J Remote Sens Sp Sci. National Authority for Remote Sensing and Space Sciences; 2017;20:283-93. 
[30] Bond JG, Casas-Martínez M, Quiroz-Martínez H, Novelo-Gutiérrez R, Marina CF, Ulloa A, et al. Diversity of mosquitoes and the aquatic insects associated with their oviposition sites along the Pacific coast of Mexico. Parasites and Vectors. 2014;7.

[31] Wulandhari SA, Pawenang ET. Analisis Spasial Aspek Kesehatan Lingkungan Dengan Kejadian Filariasis Di Kota Pekalongan. Unnes J Public Heal. 2017;6:59-67. 